IZA DP No. 7021

Higher Wages, Overstaffing or Both? The Employer's Assessment of Problems Regarding Wage Costs and Staff Level in Co-Determined Establishments

Rafael Gralla

Kornelius Kraft

November 2012 


\title{
Higher Wages, Overstaffing or Both? The Employer's Assessment of Problems Regarding Wage Costs and Staff Level in Co-Determined Establishments
}

\author{
Rafael Gralla \\ TU Dortmund \\ Kornelius Kraft \\ TU Dortmund \\ and IZA \\ Discussion Paper No. 7021 \\ November 2012 \\ IZA \\ P.O. Box 7240 \\ 53072 Bonn \\ Germany \\ Phone: +49-228-3894-0 \\ Fax: +49-228-3894-180 \\ E-mail: iza@iza.org
}

\begin{abstract}
Any opinions expressed here are those of the author(s) and not those of IZA. Research published in this series may include views on policy, but the institute itself takes no institutional policy positions. The IZA research network is committed to the IZA Guiding Principles of Research Integrity.

The Institute for the Study of Labor (IZA) in Bonn is a local and virtual international research center and a place of communication between science, politics and business. IZA is an independent nonprofit organization supported by Deutsche Post Foundation. The center is associated with the University of Bonn and offers a stimulating research environment through its international network, workshops and conferences, data service, project support, research visits and doctoral program. IZA engages in (i) original and internationally competitive research in all fields of labor economics, (ii) development of policy concepts, and (iii) dissemination of research results and concepts to the interested public.
\end{abstract}

IZA Discussion Papers often represent preliminary work and are circulated to encourage discussion. Citation of such a paper should account for its provisional character. A revised version may be available directly from the author. 


\section{ABSTRACT \\ Higher Wages, Overstaffing or Both? The Employer's Assessment of Problems Regarding Wage Costs and Staff Level in Co-Determined Establishments}

This study examines the differences in the likelihood of overpayment and overemployment in establishments with and without works councils. In contrast to other studies, we use assessments by the management concerning the existence of such problems. Furthermore, we also analyze how different types of works councils influence the probability of overemployment and overpayment. Using the wave 2006 of the IAB Establishment Panel, we show that establishments with works councils that are prepared to interfere with the management are more likely to suffer from overemployment but do not differ in the likelihood of overpayment compared to establishments without works councils. Establishments with works councils that are in line with the management, however, do not differ from establishments without a works council with regard to the likelihood of overemployment but have a lower likelihood of overpayment.

JEL Classification: J23, J31, J53

Keywords: works councils, wages, employment

Corresponding author:

Rafael Gralla

TU Dortmund

Department of Economics, Business and Social Science

Vogelpothsweg 87

44221 Dortmund

Germany

E-mail: rafael.gralla@tu-dortmund.de

\footnotetext{
* The authors thank the Research Data Centre at the Institute for Employment Research, Nuremberg for the provided data access. The financial support by the Deutsche Forschungsgemeinschaft (SFB 823, "Statistical modelling of nonlinear dynamic processes") is gratefully acknowledged.
} 


\section{INTRODUCTION}

There has been a long-standing debate in the literature on the effects of employee involvement in the operational decision-making of a firm. In Germany, wide-ranging codetermination rights are granted by law to employees, especially in personnel decisions, if they adopt a works council in their establishment. Thus works councils are, alongside unions, a powerful institution within the German system of industrial relations. The influence of such works councils has been examined since the mid1980s focusing on different topics such as productivity, R\&D, profitability, wages and employment. Starting with FitzRoy and Kraft $(1985,1987,1990)$ as well as Kraft (1986), subsequent studies controversially discuss the gains and costs of German codetermination rights ${ }^{1}$.

Almost all studies examine how objectively measured variables differ between establishments with and without works councils. In the case of wages, for example, recent studies find a remarkable wage markup in codetermined establishments ${ }^{2}$. Intuitively, this markup, in association with lower profitability, might be used in support of the hypothesis that works councils shift rents from the employer to the employees. The problem connected with these approaches, however, is that no point of reference is identified. High wages may well be justified if they are compensated by their main reference point, namely productivity. Productivity, however, may systematically differ between codetermined and non-codetermined establishments for many reasons, and may also be affected by the existence of works councils themselves. Hence, comparing the wage level between establishments with and without works councils, especially as an indication and source of rent shifting, might be misleading if economic reasons justify a difference.

The point of reference is even more complicated if employment is considered. In principle the intersection of the wage rate with the labor demand curve should be used and this would also be related to establishment-specific characteristics such as productivity but in a non-trivial way. The German codetermination rights acknowledge a profound influence on hires and dismissals. At a minimum this might lead to

\footnotetext{
${ }^{1}$ Frege (2002), Addison, Schnabel and Wagner (2004), and Jirjahn (2011) present surveys on the effects of works councils.

${ }^{2}$ See, e.g., Addison, Schnabel and Wagner (2001), Hübler and Jirjahn (2003), Gerlach and Meyer (2007), as well as Addison, Teixeira and Zwick (2010).
} 
bureaucratization and delays in personnel decisions. A potentially inefficient employment level is empirically hard to identify because the absolute employment level has to be related to the establishment's labor demand.

In contrast to other studies our approach is based on subjective assessments of expected problems by the management, namely overemployment and overpayment. The advantage of our approach is that establishment-specific heterogeneity is expected to be taken up by the managers. The assessment of the existence of overpayment and overemployment implies too large a difference between the actual levels of wage and employment and, from the employer's point of view, optimal levels of both variables rather than solely their absolute levels. As mentioned earlier, the crucial point with any statement on the appropriateness of a wage or employment level is the point of reference. In the case of wages, the relation to productivity matters and productivity will be the result of observable as well as unobservable qualification advantages or - as many argue - simply by the existence of a works council itself. Hence, in such situations a subjective evaluation of the wage level by the managers may turn out to be useful. Also, where overemployment exists, a subjective assessment by the management considers all establishment-specific background information that determines employment. This information is difficult for researchers from outside to take into account. Hence, in such circumstances, subjective appraisal by the management may be regarded as a more reliable measurement of the efficiency of an establishment's recent employment level.

In the first place, we consider the effect of the existence of a works council on both personnel issues. Subjective approaches to identify the influence of works councils on wages and employment are very rare. To our knowledge, only Gold (1999) uses a subjective measurement of overemployment as a dependent variable. Using the NIFA-Panel, he finds that managers of a codetermined establishment are more likely to report overemployment as well as excessive redundancy costs than managers of establishments without works councils.

In the next step, we additionally control for heterogeneous effects of different types of work councils. Heterogeneity in the economic consequences of works councils due to different kinds of works council's behavior has rarely been analyzed. This is probably caused by the difficulty in producing reliable classifications for works councils. Information on this issue is obviously hard to come by. Studies on the effects of 
different works council types are performed by Dilger $(2002,2006)$ and Pfeifer (2011). Dilger (2002) examines how different types of works councils (own classification by Dilger) affect hires, dismissals, and turnover in the German mechanical engineering industry. He shows that works councils that intervene in dayto-day business significantly reduce all three dependent variables. Works councils that do not intervene, however, have no significant influence. In a further study (Dilger, 2006) he takes up his approach from 2002 concerning the types of works councils and extends it by controlling for the relations between works councils and management. In addition to the results estimated in his earlier study, he now finds a reduction of subjectively measured profit levels but no effect on innovations in establishments with intervening works councils. Pfeifer (2011) shows that establishments with works councils have higher productivity, higher wages, and lower profitability. Using data which is fairly similar to ours, he also considers different types of works councils. He finds the strongest effects on productivity if works councils usually negotiate with the management and also agree to a compromise. The strongest effects on wages and profitability, however, are identified in establishment with works councils which negotiate with the management but do not usually come to a compromise. Works councils that are largely in line with the management have the weakest impact.

Using wave 2006 from the IAB Establishment Panel, we show in this paper that on average in establishments with works councils (of all types) managers are more likely to complain of too large a number of employees. However, this is not true in the case of overpayment. If we additionally control for different types of works councils, we find strong evidence for heterogeneity: managers of establishments with negotiating works councils are more likely to complain of overemployment but are not more likely to complain of overpayment. In establishments with works councils that are mostly in line with the management, however, we find no higher likelihood of overemployment and in fact a lower probability for the existence of overpayment.

This paper is organized as follows: in the next section, we discuss the legal background and theories regarding codetermination. In the $3^{\text {rd }}$ section, we describe our data and variables. Section 4 contains an explanation of the econometric model that we use and a discussion of our results. Furthermore, Section 5 contains 
inferences using an objective measured variable, namely labor costs. Finally, we conclude in Section 6.

\section{LEGAL AND THEORETICAL BACKGROUND}

The source of German codetermination rights is the Works Constitution Act (Betriebsverfassungsgesetz). It allows the staff of every establishment with at least five employees to adopt a works council and provides, compared to other countries, extensive rights to information, consultation and codetermination. Codetermination rights mainly exist with respect to social and workplace-related aspects within an establishment. For example, works councils are able to prevent dismissals if these dismissals neglect social aspects such as age or family background. Another reason for intervention is if (in the view of the works council) further employment (possibly after retraining) is feasible. Furthermore, they can also veto with respect to a hiring if it is thought that the person to be hired will disturb the peace within the establishment (Betriebsfrieden) or the works council fears that the new employee will substitute permanent staff without an operational need for this reorganization. In the case of collective redundancies, works councils have to negotiate what is referred to as "social plans". These plans determine redundancy payments and the periods of notice.

The influence of works councils on wages is limited. Firstly, works councils are not allowed to participate directly in wage negotiations. Nor are they allowed to call strikes, and therefore they are not able to initiate the strongest form of industrial action. Furthermore, they cannot change parts of a collective bargaining agreement as long as no "opening clause" (Öffnungsklausel) of the agreement explicitly allows such an interference. Nevertheless, works councils are able to influence wages indirectly. If, for example, an establishment makes use of profit sharing, the works council has to bargain the organization and extent of such payments. Furthermore, works councils can negotiate benefits that go beyond the scale of collective bargaining agreements. Finally, collective bargaining agreements only define wage groups (Lohngruppen). Works councils and employers, however, have to determine which wage group should be used for a particular vacancy. Therefore, works councils indirectly define the wage that a particular worker earns. 
The theory of codetermination is highly controversial. Jirjahn (2005) provides a detailed discussion about the possible effects of works councils from a theoretical point of view. On the one hand, in line with the property rights theory, it is argued that works councils negatively affect the economic performance of an establishment. They reduce its flexibility and adaptability to market conditions by reducing the room for maneuver of the management. Furthermore, they use their bargaining power resulting from codetermination rights to shift rents from the employer to employees. This will ultimately reduce profits, and obviously lower expected profits will also negatively affect the incentives to invest in such an establishment.

As stated above, works councils are able to prevent or, at least, delay dismissals. One might therefore expect less flexibility where dismissals are inevitable for economic reasons. Based on this theory, it could be assumed that establishments with works councils will more often suffer from personnel problems and also realize a wage-employment relation which is off the profit-maximizing labor demand curve. This would be a contradiction to the popular Right-to-Manage approach and establishments with works councils would in this case more frequently state that overemployment prevails if works councils exist ${ }^{3}$. Overemployment may be a shortor long-term phenomenon. Most people will interpret it as a temporary phenomenon as management will find ways to reduce employment to its optimal level over time. Additionally, if overemployment were actually a permanent phenomenon, the management would simultaneously state that they expect to have overpayment because overemployment stands for a solution to the right of the labor demand curve. Then the wage would be higher than productivity. A major exception to this argumentation would be the existence of efficient contracts where the wageemployment combination must be off the labor demand curve. In this case it would always be in the interest of the management to reduce employment (and to breach the efficient contract) ${ }^{4}$.

On the other hand, participation theory argues that codetermination can increase an establishment's performance. Works councils improve communication between

\footnotetext{
${ }^{3}$ See Booth (1995) for a detailed discussion of different approaches to modeling labor market bargaining.

${ }^{4}$ Please note that in this case we implicitly assume that, in addition to wages, employment is part of the works council's utility function.
} 
employees and management in such a way that efficiency gains occur. Another line of argument is that the information rights granted to works councils may lead to reduced information asymmetries within an establishment. This would enable agreements to be reached which otherwise would not have been possible.

Freeman and Lazear (1995), for example, argue that the information rights of works councils can decrease the likelihood of bankruptcy for an establishment. The reason being as follows: information asymmetries prevent the implementation of some pareto-efficient agreements between managers and employees if an ex-post break of such an agreement increases manager's but decreases employee's pay-offs. If the employees are aware of the incentives to break an agreement they would refuse such offers right away. In an unfavorable economic situation, for example, employees could decrease their claims toward the establishment in order to save their jobs if they trust the senior management. If a works council does not exist in an establishment, such concessions are less likely because the employees would then expect manager to exaggerate the gravity of the economic situation. With respect to our study, if participation theory describes reality well, establishments with works councils would be less likely to report personnel problems.

\section{DESCRIPTIVE STATISTICS}

The aim of this study is to analyze how the existence of a works council influences the likelihood of an establishment suffering from overemployment and overpayment. As mentioned earlier, the innovative aspect of our study is the use of subjective evaluation by the senior management concerning perceived problems. Whilst subjective assessments are sometimes regarded as unreliable, the advantage of this approach in our view is that the management uses its perception of an optimal situation as a benchmark on which to base its assessment. This includes the location of the labor demand curve (from the view of the managers). Hence, this approach enables us to identify whether the relation between wage and labor is on or off the labor demand curve.

This study uses the IAB Establishment Panel, Wave 2006. Access to the data was provided via remote access at the Research Data Centre (FDZ) of the German 
Federal Employment Agency (BA) at the Institute for Employment Research $(\mathrm{IAB})^{5}$. This panel is an annual survey of more than 15,000 German establishments. For the purpose of our study, we are only able to use data from 2006 because this is the only wave with information on the relations between works councils and management, which are subsequently used to differentiate between types of works councils. We restrict our sample to establishments with at least five employees because smaller establishments are not allowed to adopt a works council. Furthermore, we drop observations from agriculture, nonprofit organizations, and public administration. Finally, our sample contains 5940 observations. Table 1 shows means and standard deviations of our variables.

We examine the influence of works councils on two dichotomous variables. The first variable, overemployment, has unit value if the management of the establishment states that they expect to have too many employees during the next two years. In our sample, 9.7 percent of the establishments surveyed report that they expect such a problem. The second dependent variable is overpayment. This variable takes unit value if an establishment foresees a high financial burden on wage costs during the next two years. 36.9 percent of all establishments state that they are confronted with this problem.

In section 5, we will also use an objective measure as dependent variable, i.e. wages, in order to draw additional inferences. The IAB Establishment Panel contains just one piece of information regarding labor costs: the establishments state the total amount of gross pay in the month of June 2006 excluding the employer's social security contribution. We divide this variable by the number of employees and use its logarithmic value as a proxy for mean monthly $\ln ($ wage).

\footnotetext{
${ }^{5}$ For a detailed description of the IAB Establishment Panel, see Kölling (2000).
} 
Table 1

Descriptive statistics

\begin{tabular}{lcc} 
Variable & Mean & Std. dev. \\
\hline Overemployment & 0.097 & 0.296 \\
Overpayment & 0.369 & 0.482 \\
\hline Works council & 0.354 & 0.478 \\
Works council (type A) & 0.277 & 0.448 \\
Works council (type B) & 0.077 & 0.267 \\
Increasing Sales & 0.322 & 0.467 \\
Decreasing Sales & 0.139 & 0.345 \\
Saturday & 0.670 & 0.470 \\
Temporary work & 0.020 & 0.059 \\
Technology & 0.703 & 0.457 \\
Collect. agreement (firm level) & 0.090 & 0.286 \\
Collect. agreement (industry level) & 0.442 & 0.497 \\
Outsource & 0.037 & 0.188 \\
Insource & 0.033 & 0.178 \\
Single establishment & 0.709 & 0.454 \\
Share of low-educated workers & 0.183 & 0.252 \\
Share of highly educated workers & 0.087 & 0.157 \\
Share of part-time contracts & 0.152 & 0.205 \\
Share of fixed term contracts & 0.052 & 0.118 \\
Active owner & 0.478 & 0.500 \\
Labor costs per employee & 2102.862 & 971.766 \\
Employment & 138.498 & 290.833 \\
\hline No. of obs. & &
\end{tabular}

Note: Due to missing values, Labor costs is only observed in 5281 establishments.

Our main independent variable is works council. This is a dummy variable that has unit value if a works council exists in an establishment. In our sample, 35.4 percent of all establishments have a works council. This is a high share of codetermined establishments. Beckmann, Föhr and Kräckel (2010) use representative data and show that $13.7 \%$ of all German establishments with more than 5 employees had a works council in 2006. Our relatively high number of codetermined establishments results from the fact that the likelihood of the existence of a works council increases with establishment size and large establishments are overrepresented in the IAB Establishment Panel. In a second part of our study, we consider different types of 
works council. The types are defined according to the behavior of a works council towards the management. We test empirically whether the estimated effects depend on the type of works council or not.

The industrial relations-oriented literature on works councils has been discussing for some time how the types of works councils can be distinguished. Kotthoff (1981, 1994) identifies 6 types of works councils, namely isolated, ignored, behaving as a part of the management, autonomous, respected, and cooperative but exerting countervailing power. Nienhüser (2005) characterizes the first three types of works councils as weak works councils and the last three types as strong works councils.

The IAB Establishment Panel does not contain as much differentiated information about different types of works councils. Instead, for our purpose, we just use two different types of works councils based on evaluations by the management. Originally the management was given the three following alternatives (only one statement is possible):

1 Business decisions usually have to be put through against the works/staff council.

2 The works/staff council often diverges from the management's opinion when it comes to business decisions; nevertheless a consensual solution is eventually found in most cases.

3 Most business decisions are mutually agreed upon by the works/staff council and the management.

Alternative 1 has only been selected by about 1\% of all observations. As this low number implies too few observations for a useful empirical test, we merge option 1 and 2 to what we call works council type $A$. The second kind of works council is of a more cooperative type and we call them works council type $B$. While the management in 27.7 percent of all establishments reports having a works council of the first type, the second type only exists in 7.7 percent of all observations. Hence, put differently for those establishments where a works council exists, 78.2 percent of all managers asses their work council as being of type $A$ and 21.8 percent of all managers asses their works council as a type B representative body. Clearly this 
dichotomization aims at distinguishing works councils according to how vigorously worker interests are pursued. Some may prefer to call the type A works council a strong one and the type B works council a weak one.

The way the works councils behave will affect their bargaining power and, as bargaining power is mainly used for rent-sharing activities, type B works councils are expected to be less successful in claiming rents. If this hypothesis is true and wages and employment are part of the utility function of works councils, in both areas less problems are expected to be stated compared to the situation when a type A works council is present.

We consider several additional covariates. First we control for expected changes in sales in 2006. If, sales are expected to increase in the near future, the management will probably less frequently state that overemployment is a problem. In contrast, if the sales forecast is pessimistic, problems will be more likely because fewer employees are necessary.

In order to control for expected changes in sales and also for different effects of decreasing or increasing sales, we generate two different dummy variables. The variable increasing sales has unit value if sales in 2006 are expected to increase and equals zero if sales stagnate or decrease. In contrast, the variable decreasing sales has unit value if sales are expected to decrease in 2006 and equals zero otherwise.

Furthermore, it is possible that flexibility in employment and working time may also affect the existence of personnel problems. In order to control for employment flexibility we add the variable temporary work into our model. This variable is defined as the ratio of temporary workers to all employees. A higher share of temporary work increases the flexibility of the management to react to personnel problems, especially to overemployment.

Such flexibility can also be reached through fixed-term contracts. Hence, we generate the variable share of fixed term contracts, i.e. the number of employees with a fixed term contract divided by total employment. A high share of fixed term contracts enables a fairly smooth adjustment of employment in the short run simply by not extending such contracts. Hence problems with overemployment should be less frequently reported. 
As an alternative to adjusting the number of workers, the number of hours may be altered if necessary. This hypothesis is considered by the variable Saturday, which is a dummy variable that has unit value if the employees of an establishment work Saturdays on demand.

Part-time employment might also affect adjustment behavior by increasing the possibilities of the management to deploy the employees. If this were true, overemployment should pose less of a problem. We measure the influence of working time flexibility by share of part-time contracts. Share of part-time contracts is the share of employees with part-time contracts divided by total employment.

We also control for the influence of collective bargaining agreements. In Germany, two different kinds of collective bargaining agreements exist. Usually, unions and employer's associations negotiate wages at industry level. Hence, we add the dummy collect. agreement (industry level) to our model and this dummy has unit value if the establishment is covered by such a collective bargaining agreement. As an alternative to industry-wide agreements, however, a company and a union can agree to a collective bargaining agreement at company level. We also control for the effect of such agreements by the dummy collect. agreement (firm level).

Furthermore, we control for the influence of the use of a more or less advanced technology by the establishment. In the IAB Establishment Panel the management has to rate its technology compared to other establishments of the same industry, on a five-level Likert scale where 1 means "state-of-the-art" and 5 "obsolete". We generate a dummy technology that has unit value if the management rates its technology with 1 or 2 . The effect of technological advance is ambiguous. On the one hand, advanced technology could reduce production costs so the firm would achieve a competitive advantage in comparison to its rivals. This would positively affect growth and employment prospects. If this were true, less personnel problems should be expected. On the other hand, advanced technology could also be applied to substitute labor. Hence, overemployment in particular would arise, at least temporarily.

If an establishment has to implement strong structural adjustments, the probability of personnel problems might be affected. Insourcing and outsourcing in particular are likely to influence the expectation of problems with respect to overemployment if the 
labor force cannot be adjusted smoothly. To take account of possible influences of this kind we add two dummy variables, insource and outsource. Insource has unit value if other establishments or establishment units have been integrated into the observed establishment. In this case personnel problems could arise if the integrated units are suboptimally adapted. Outsource has unit value if parts of the observed establishment are outsourced. Outsourcing is a method of reducing recent problems in an establishment. Hence, there may be less likelihood of problems in the future.

Additionally, we add the dummy single establishment in order to distinguish between single establishments and establishments that are part of a multi-site company. Multisite companies have the option of relocating capacities between different establishments, implying that problems regarding labor costs and employment can be reduced more easily. Hence, it can be expected that single establishments are more likely to suffer from personnel problems.

Furthermore, we also take the qualification level of employees into account. For this purpose, we add two variables to our regression. The variable share of low-educated workers is defined as the number of less skilled employees divided by total employment. In contrast, share of highly educated workers is defined as the share of employees with a university degree.

In addition, active involvement of the capital owners in decision making could influence the probability of assessing the recent employment level and wage level as overemployment and overpayment. In many cases companies are nowadays led by managers who do not hold any capital shares. Their decisions on wage and employment levels only indirectly affect their personal income. This is obviously different for capital owners and therefore the assessment as to whether a problem exists or not may be determined by capital ownership.

An active owner might state such problems because overemployment and overpayment reduce profits. Hence, it is the owner's business income that is directly involved. In contrast, the remuneration of an employed manager does not depend, or at most only partially depends, on the establishment's profits so that his or her perception of personnel problems might be less sensitive. We control for the influence of active ownership through the dummy active owner that has unit value if 
at least one owner or a family member of the owner works in the establishment ${ }^{6}$. In order to take size effects into account, we add several size dummies to our regression. Finally, we also add industry dummies and state (German Bundesländer) dummies to our model to control for state specific effects and industry specific effects.

\section{METHOD AND RESULTS}

The aim of this study is to analyze the influence of works councils on two binary variables. As OLS ignores the discreteness of our dependent variables and also leads to predictions above zero and below one, we estimate a Probit model. Clearly, we could estimate two univariate Probit models. This, however, would ignore a potential correlation between the error terms of both equations. Hence, we estimate a bivariate Probit model that accounts for correlated disturbances. This model can be deduced from a generalized index function model with two latent variables $\mathrm{y}_{1}$ * and $\mathrm{y}_{2}$ * that may be correlated ${ }^{7}$. These variables are defined as:

$$
\begin{aligned}
& \mathrm{y}_{1}^{*}=\mathrm{x}_{1}^{\mathrm{T}} \beta_{1}+\mathrm{u}_{1}, \quad \mathrm{y}_{1}=1 \text { if } \mathrm{y}_{1}^{*}>0,0 \text { otherwise, } \\
& \mathrm{y}_{2}^{*}=\mathrm{x}_{2}^{\mathrm{T}} \beta_{2}+\mathrm{u}_{2}, \quad \mathrm{y}_{2}=1 \text { if } \mathrm{y}_{2}^{*}>0,0 \text { otherwise, }
\end{aligned}
$$

where $u_{1}$ and $u_{2}$ are joint normal with zero means, variances one, and correlation $\rho$. If $\rho=0$, two separate Probit models could be estimated because both error terms are independent. However, if $\rho \neq 0$, two independently estimated Probit equations would be inefficient. The bivariate Probit model relaxes the assumption of independence. Here, the bivariate normal cdf is

$$
\Phi\left(x_{1}^{\mathrm{T}} \beta_{1}, \mathrm{x}_{2}^{\mathrm{T}} \beta_{2}, \rho\right)=\int_{-\infty}^{\mathrm{x}_{1}^{\mathrm{T}} \beta_{1}} \int_{-\infty}^{\mathrm{x}_{2}^{\mathrm{T}} \beta_{2}} \phi\left(\mathrm{z}_{1}, \mathrm{z}_{2}, \rho\right) d \mathrm{z}_{1} \mathrm{dz} \mathrm{z}_{2}
$$

where

\footnotetext{
${ }^{6}$ The wave 2006 of the IAB Establishment Panel does not contain detailed information about the position of the owner in the establishment. We only know how many working proprietors and unpaid family members are employed in the establishment. Although this information does not ensure that the proprietor manages the establishment, we use this variable as a proxy for active management by the owner because it is unlikely that the owner of an establishment does not have the last word in the decision-making at his or her establishment.
}

${ }^{7}$ For a detailed discussion about bivariate Probit models, see Greene (2008). 


$$
\phi\left(x_{1}^{\mathrm{T}} \beta_{1}, x_{2}^{\mathrm{T}} \beta_{2}, \rho\right)=\frac{\mathrm{e}^{-\frac{1}{2\left(1-\rho^{2}\right)}\left(\left(\mathrm{x}_{1}^{\mathrm{T}} \beta_{1}\right)^{2}+\left(\mathrm{x}_{2}^{\mathrm{T}} \beta_{2}\right)^{2}-2 \rho \mathrm{x}_{1}^{\mathrm{T}} \beta_{1} \mathrm{x}_{2}^{\mathrm{T}} \beta_{2}\right)}}{2 \pi\left(1-\rho^{2}\right)^{\frac{1}{2}}}
$$

Therefore, the log likelihood function is

$$
\ln \mathrm{L}=\sum_{\mathrm{i}=1}^{\mathrm{N}} \ln \Phi\left(\mathrm{q}_{\mathrm{i} 1} \mathrm{x}_{\mathrm{i} 1}^{\mathrm{T}} \beta_{1}, \mathrm{q}_{\mathrm{i} 2} \mathrm{x}_{\mathrm{i} 2}^{\mathrm{T}} \beta_{2}, \rho_{\mathrm{i}}^{*}\right)
$$

with

$$
\begin{array}{r}
\mathrm{q}_{\mathrm{i} 1}=2 \mathrm{y}_{\mathrm{i} 1}-1, \\
\mathrm{q}_{\mathrm{i} 2}=2 \mathrm{y}_{\mathrm{i} 2}-1,
\end{array}
$$

and

$$
\rho_{\mathrm{i}}^{*}=\mathrm{q}_{\mathrm{i} 1} \mathrm{q}_{\mathrm{i} 2} \rho
$$

Within this framework, we estimate two different models. The model is based on the following equations

$$
\text { Overemployment }_{\mathrm{i}}=\alpha_{1}+\beta_{1} \mathrm{~W}_{\mathrm{i}}+\gamma_{1} \mathrm{X}_{\mathrm{i}}^{\mathrm{T}}+\mathrm{u}_{\mathrm{i} 1}
$$

and

$$
\text { Overpayment }_{\mathrm{i}}=\alpha_{2}+\beta_{2} \mathrm{~W}_{\mathrm{i}}+\gamma_{2} \mathrm{X}_{\mathrm{i}}^{\mathrm{T}}+\mathrm{u}_{\mathrm{i} 2} \text {. }
$$

In the first model, $W_{i}$ is substituted by the works council dummy. Hence, this model treats works councils in accordance with almost all literature as a unitary variable. The second model contains the variables works council (type A) and works council (type $B$ ) instead of the variable works council. So it additionally controls for potential heterogeneity in works councils behavior.

Table 2 shows the results of our estimates and the first two columns contain our estimates without controlling for heterogeneity of works councils. The last two columns show the estimated effects of different kinds of works councils. A Wald test 
always rejects independence of overemployment and overpayment so that a correlation between both error terms exists ${ }^{8}$.

Regarding the results which are based on the simple distinction of whether a works council exists or not, we find that establishments with a works council are more likely to suffer from overemployment. Overpayment, however, does not occur more frequently in codetermined establishments. If we control for heterogeneity of works councils, we find different results: type A works councils increase the likelihood of overemployment and do not affect the likelihood of overpayment. In contrast, type B works councils do not affect the likelihood of overemployment and even reduce the likelihood of overpayment.

Most of the control variables work well in both models. If sales are expected to increase, the probability that overemployment problems will be reported is reduced. In contrast, if sales are expected to decrease, in the view of the managers both overemployment and overpayment become more probable. The use of temporary work decreases the likelihood that overemployment will be a problem during the next two periods. Advanced technology reduces expected problems with respect to employment and payment. Hence, advanced technology appears to affect employment prospects positively. Collective bargaining at industry level is connected with more complaints by managers concerning expected overpayment.

Insourcing always leads to a higher likelihood of problems observed with overemployment as well as with overpayment in the near future. In contrast to our stated hypothesis, managers from single establishments do not expect problems with respect to overpayment and with respect to overemployment. Low and high qualification levels have the expected effects with respect to the probability that overpayment problems are stated. Active ownership has no effect on overemployment. The management from these establishments, however, more frequently state overpayment, which could be explained by a more aggressive counteraction against higher wages.

\footnotetext{
${ }^{8}$ The $p$-values of these tests are in the third from last row of each table.
} 
Table 2

Regression results (full sample)

\begin{tabular}{|c|c|c|c|c|}
\hline \multicolumn{5}{|c|}{ Bivariate Probit } \\
\hline Variables & \multicolumn{2}{|c|}{$\begin{array}{c}\text { Coeff. } \\
\text { (Std.error) } \\
\end{array}$} & \multicolumn{2}{|c|}{ 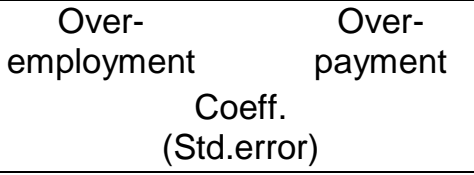 } \\
\hline Works council & $\begin{array}{l}0.323^{\star * \star} \\
(0.072)\end{array}$ & $\begin{array}{l}-0.044 \\
(0.053)\end{array}$ & \multirow[b]{2}{*}{$\begin{array}{l}0.392^{\star \star \star} \\
(0.076)\end{array}$} & \multirow[b]{2}{*}{$\begin{array}{c}0.035 \\
(0.057)\end{array}$} \\
\hline Works council (Type A) & & & & \\
\hline Works council (Type B) & & & $\begin{array}{c}0.149 \\
(0.103)\end{array}$ & $\begin{array}{l}-0.242^{\star \star \star} \\
(0.073)\end{array}$ \\
\hline Increasing sales & $\begin{array}{l}-0.190 * \star * \\
(0.059)\end{array}$ & $\begin{array}{c}0.045 \\
(0.039)\end{array}$ & $\begin{array}{l}-0.187^{\star \star \star} \\
(0.059)\end{array}$ & $\begin{array}{c}0.047 \\
(0.039)\end{array}$ \\
\hline Decreasing sales & $\begin{array}{l}0.697^{\star \star \star} \\
(0.061)\end{array}$ & $\begin{array}{l}0.156^{\star \star \star} \\
(0.051)\end{array}$ & $\begin{array}{l}0.696 * \star \star \\
(0.061)\end{array}$ & $\begin{array}{l}0.154^{\star \star \star} \\
(0.051)\end{array}$ \\
\hline Saturday & $\begin{array}{c}0.030 \\
(0.055)\end{array}$ & $\begin{array}{l}0.141^{\star * *} \\
(0.039)\end{array}$ & $\begin{array}{c}0.028 \\
(0.055)\end{array}$ & $\begin{array}{l}0.141^{\star \star *} \\
(0.039)\end{array}$ \\
\hline Temporary work & $\begin{array}{l}-1.932^{\star \star *} \\
(0.624)\end{array}$ & $\begin{array}{c}0.248 \\
(0.300)\end{array}$ & $\begin{array}{l}-1.979 * \star \star \\
(0.638)\end{array}$ & $\begin{array}{c}0.216 \\
(0.301)\end{array}$ \\
\hline Technology & $\begin{array}{l}-0.115^{\star \star} \\
(0.052)\end{array}$ & $\begin{array}{l}-0.103^{\star \star *} \\
(0.038)\end{array}$ & $\begin{array}{l}-0.112^{\star *} \\
(0.052)\end{array}$ & $\begin{array}{l}-0.100 * \star \star \\
(0.038)\end{array}$ \\
\hline $\begin{array}{l}\text { Collect. agreement } \\
\text { (firm level) }\end{array}$ & $\begin{array}{l}-0.033 \\
(0.091)\end{array}$ & $\begin{array}{c}0.040 \\
(0.067)\end{array}$ & $\begin{array}{l}-0.036 \\
(0.091)\end{array}$ & $\begin{array}{c}0.034 \\
(0.067)\end{array}$ \\
\hline $\begin{array}{l}\text { Collect. agreement } \\
\text { (industry level) }\end{array}$ & $\begin{array}{c}0.009 \\
(0.059)\end{array}$ & $\begin{array}{l}0.085^{\star \star} \\
(0.042)\end{array}$ & $\begin{array}{c}0.004 \\
(0.059)\end{array}$ & $\begin{array}{r}0.079 * \\
(0.042)\end{array}$ \\
\hline Outsource & $\begin{array}{c}0.143 \\
(0.120)\end{array}$ & $\begin{array}{c}0.117 \\
(0.091)\end{array}$ & $\begin{array}{c}0.140 \\
(0.108)\end{array}$ & $\begin{array}{c}0.109 \\
(0.091)\end{array}$ \\
\hline Insource & $\begin{array}{l}0.254^{* *} \\
(0.120)\end{array}$ & $\begin{array}{l}0.231^{* *} \\
(0.094)\end{array}$ & $\begin{array}{l}0.238^{\star *} \\
(0.120)\end{array}$ & $\begin{array}{l}0.214^{\star \star \star} \\
(0.094)\end{array}$ \\
\hline Single establishment & $\begin{array}{l}-0.019 \\
(0.059)\end{array}$ & $\begin{array}{c}0.054 \\
(0.044)\end{array}$ & $\begin{array}{l}-0.012 \\
(0.059)\end{array}$ & $\begin{array}{c}0.062 \\
(0.044)\end{array}$ \\
\hline $\begin{array}{l}\text { Share of low-educated } \\
\text { workers }\end{array}$ & $\begin{array}{c}0.088 \\
(0.111)\end{array}$ & $\begin{array}{l}0.186 \star \star \\
(0.079)\end{array}$ & $\begin{array}{c}0.092 \\
(0.111)\end{array}$ & $\begin{array}{l}0.188^{\star *} \\
(0.079)\end{array}$ \\
\hline $\begin{array}{l}\text { Share of highly educated } \\
\text { workers }\end{array}$ & $\begin{array}{l}-0.008 \\
(0.184)\end{array}$ & $\begin{array}{l}-0.350 * * \\
(0.139)\end{array}$ & $\begin{array}{l}-0.013 \\
(0.185)\end{array}$ & $\begin{array}{l}-0.360 * \star \star \\
(0.139)\end{array}$ \\
\hline Share of part-time contracts & $\begin{array}{c}0.042 \\
(0.135)\end{array}$ & $\begin{array}{l}-0.041 \\
(0.102)\end{array}$ & $\begin{array}{c}0.051 \\
(0.135)\end{array}$ & $\begin{array}{l}-0.033 \\
(0.102)\end{array}$ \\
\hline $\begin{array}{l}\text { Share of fixed term } \\
\text { contracts }\end{array}$ & $\begin{array}{l}-0.266 \\
(0.231)\end{array}$ & $\begin{array}{l}-0.086 \\
(0.146)\end{array}$ & $\begin{array}{l}-0.228 \\
(0.230)\end{array}$ & $\begin{array}{l}-0.062 \\
(0.147)\end{array}$ \\
\hline Active owner & $\begin{array}{l}-0.019 \\
(0.057)\end{array}$ & $\begin{array}{l}0.269 \star \star \star * \\
(0.042)\end{array}$ & $\begin{array}{l}-0.013 \\
(0.057)\end{array}$ & $\begin{array}{l}0.275^{\star \star \star} \\
(0.042)\end{array}$ \\
\hline p-value of Wald test $[\rho=0]$ & & & & \\
\hline McFadden- $\mathrm{R}^{2}$ & & & & \\
\hline No. of obs. & & & & \\
\hline
\end{tabular}

Notes: * statistically significant at 0.10 level; ** at 0.05 level; ** at 0.01 level. Size dummies, state dummies and industry dummies are included but not reported. Robust standard errors in parenthesis. 
In a Probit model, the estimated coefficients cannot be interpreted as marginal effects. Hence, we calculate the influence of the existence of a works council on overemployment and overpayment by calculating the difference between the average predicted probabilities of codetermined and non-codetermined establishments. These marginal effects are presented in Table 3. The standard errors of the marginal effects are calculated by the delta method. As we are only interested in the marginal effects of works councils, we waive to show the effects of the other variables for reasons of clarity. Additionally, we calculate semi-elasticities in order to control for the relative effect of a works council. Remember that only 9.7 percent of all establishments suffer from overemployment, but 36.9 percent of all establishments suffer from overpayment. Hence, solely interpreting the absolute effect (i.e. marginal effect) of the works council dummies might lead to a distorted picture. As with marginal effects, we calculate semi-elasticities by calculating the difference between the average logarithm of the predicted probability of stating problems of codetermined and noncodetermined establishments. That is, the average semi-elasticity of a dependent variable is $\frac{1}{\mathrm{~N}} \sum_{\mathrm{i}=1}^{\mathrm{N}} \mathrm{SE}_{\mathrm{Y}_{\mathrm{i}}}$ whereas

$$
\mathrm{SE}_{\mathrm{Y}_{\mathrm{i}}}=\ln \left(\mathrm{Y}_{\mathrm{i}} \mid \text { Works council }_{\mathrm{i}}=1\right)-\ln \left(\mathrm{Y}_{\mathrm{i}} \mid \text { Works council }_{\mathrm{i}}=0\right) \text {, }
$$

and $Y_{i}$ is the probability that the management states that its establishment suffers from overemployment and overpayment. The estimated semi-elasticities are also shown in Table 3.

Regarding the marginal effect of works council, we find that the likelihood that an establishment with a works council will suffer from overemployment is 5.1 percentage points higher than the likelihood in an establishment without a works council. Expressed in relative terms, works councils increase the likelihood of overemployment by 60.4 percent. The likelihood of the existence of problems with overpayment in codetermined establishments does not significantly differ from the likelihood in establishments without a works council. Summarizing, these results 
show that the existence of a works council implies a higher likelihood of finding a wage-labor relation that is off the labor demand curve ${ }^{9}$.

Regarding the results with works councils differentiated according to their type, we find a strong heterogeneity in our results: the likelihood that an establishment will suffer from overemployment increases by 6.5 percentage points if its works council has been classified as being of type A. Expressed in proportional terms, the likelihood that the management of such an establishment will state overemployment increases by 72.0 percent. In contrast, we find no significant effect on overpayment.

Table 3

Effects of works councils on overemployment and on overpayment (full sample)

\begin{tabular}{|c|c|c|}
\hline Variables Dep. Var. & $\begin{array}{l}\text { Overemployment } \\
\text { Marginal effects } \\
\text { (Std. error) }\end{array}$ & $\begin{array}{l}\text { Overpayment } \\
\text { Marginal effects } \\
\text { (Std. error) }\end{array}$ \\
\hline Works council & $\begin{array}{l}0.051^{\star \star *} \\
(0.012)\end{array}$ & $\begin{array}{l}-0.015 \\
(0.019)\end{array}$ \\
\hline Works council (Type A) & $\begin{array}{l}0.065^{\star \star \star} \\
(0.014)\end{array}$ & $\begin{array}{c}0.013 \\
(0.020)\end{array}$ \\
\hline Works council (Type B) & $\begin{array}{c}0.024 \\
(0.018)\end{array}$ & $\begin{array}{l}-0.083^{\star * \star} \\
(0.024)\end{array}$ \\
\hline \multirow{3}{*}{$\begin{array}{l}\mathrm{p} \text {-value of F-test } \\
\mathrm{ME}_{\text {WoCo Type A }}=\mathrm{ME}_{\text {WoCo Type B }}\end{array}$} & & \\
\hline & 0.012 & $<0.001$ \\
\hline & $\begin{array}{l}\text { Semi-elasticities } \\
\text { (Std. error) }\end{array}$ & $\begin{array}{l}\text { Semi-elasticities } \\
\text { (Std. error) }\end{array}$ \\
\hline Works council & $\begin{array}{l}0.604^{\star \star \star} \\
(0.133)\end{array}$ & $\begin{array}{l}-0.046 \\
(0.056)\end{array}$ \\
\hline $\begin{array}{l}\text { Works council } \\
\text { Type A }\end{array}$ & $\begin{array}{l}0.720 * \star \star \\
(0.135)\end{array}$ & $\begin{array}{c}0.037 \\
(0.059)\end{array}$ \\
\hline $\begin{array}{l}\text { Works council } \\
\text { Type B }\end{array}$ & $\begin{array}{c}0.277 \\
(0.186)\end{array}$ & $\begin{array}{l}-0.272^{\star * *} \\
(0.088)\end{array}$ \\
\hline $\begin{array}{l}p \text {-value of F-test } \\
S E_{\text {WoСo Туре A }}=S E_{\text {ШоСо Туре B }}\end{array}$ & 0.008 & $<0.001$ \\
\hline
\end{tabular}

Notes: * statistically significant at 0.10 level; ${ }^{* *}$ at 0.05 level; ${ }^{* *}$ at 0.01 level. Standard errors are calculated by the delta method.

${ }^{9}$ Due to our cross-sectional data, we are not able to control whether overemployment is permanent or just the result of a delaying of necessary adjustment of employment by works councils. 
Works councils that are in line with the management (works council type $B$ ), however, have quite different effects. Here, the management does not report overemployment more frequently than establishments without works councils. Surprisingly, we find a strong negative impact on the likelihood of overpayment. This likelihood is reduced by 8.3 percentage points for establishments with works councils of type B which is, in relative terms, a reduction of 27.2 percent $^{10}$.

A Wald test also rejects equality of the marginal effects at 5\%-level ( $p$-value: 0.012 ) and of the semi-elasticities ( $p$-value: 0.008) in the overemployment equation. In the overpayment equation, equality can also be rejected. The p-values of the marginal effect and the semi-elasticity are $p<0.001$.

The Works Constitution Act grants a works council extended codetermination rights if an establishment employs more than 20 workers. Works councils in larger establishments have additional codetermination rights regarding hires and the transfer of employees. Furthermore, the management must also keep the works council informed at least once every quarter about the economic situation of the establishment ${ }^{11}$. Due to the fact that these additional rights especially concerning employment increase the bargaining power of a works council, we repeat our estimates with a subsample that only contains establishments with more than 20 employees. Table A1 in the appendix shows the estimated coefficients of all covariates based on this subsample. Table 4 contains the estimated marginal effects and semi-elasticities of our main independent variables.

Compared to the estimates with the complete sample, we find slightly different results regarding the existence of overemployment and overpayment in codetermined establishments. Without controlling for heterogeneity of works councils, the estimated difference in the likelihood that the establishments suffer from overemployment is 5.3

\footnotetext{
${ }^{10}$ A potential limitation of our approach is a selectivity-induced bias. Whether a works council exists or not is decided by the employees. Therefore, the possibility cannot be excluded that the existence of a works council is not random. Thus, if we do not control for the reason of existence, our results will be biased. Due to our cross-sectional data, we are not able to use panel methods to control for such selectivity. Furthermore, we do not have appropriate instruments. However, our variables defuse a potential selectivity problem. Jirjahn (2011) argues that works councils are introduced in establishments which expect a worsening of the economic situation. In contrast to other studies, we control for expectations through the variables increasing sales and decreasing sales so that an omitted variable bias caused by expectations should pose less of a problem or none at all.

${ }^{11}$ See Pulte (2009) for a more detailed description of the link between firm size and codetermination rights.
} 
percentage points (i.e. 56.8 percent) higher than in establishments without works councils. Hence, in absolute as well as relative terms, the effect is similar to the previous results based on the full sample. We also find no significant effect on the existence of overpayment.

Table 4

Effects of works councils on overemployment and on overpayment $(\mathrm{N}>20)$

\begin{tabular}{|c|c|c|}
\hline Variables Dep. Var. & $\begin{array}{l}\text { Overemployment } \\
\text { Marginal effects } \\
\text { (Std. error) }\end{array}$ & $\begin{array}{l}\text { Overpayment } \\
\text { Marginal effects } \\
\text { (Std. error) }\end{array}$ \\
\hline Works council & $\begin{array}{l}0.053^{\star * *} \\
(0.013)\end{array}$ & $\begin{array}{l}-0.008 \\
(0.021)\end{array}$ \\
\hline Works council (Type A) & $\begin{array}{l}0.067^{\star * \star} \\
(0.015)\end{array}$ & $\begin{array}{c}0.023 \\
(0.023)\end{array}$ \\
\hline Works council (Type B) & $\begin{array}{c}0.028 \\
(0.021)\end{array}$ & $\begin{array}{l}-0.083^{* * *} \\
(0.027)\end{array}$ \\
\hline \multirow{3}{*}{$\begin{array}{l}\mathrm{p} \text {-value of F-test } \\
\mathrm{ME}_{\text {WoСo Type A }}=\mathrm{ME}_{\text {WoСо Туре B }}\end{array}$} & & \\
\hline & 0.030 & -0.001 \\
\hline & $\begin{array}{l}\text { Semielasticities } \\
\text { (Std. error) }\end{array}$ & $\begin{array}{l}\text { Semielasticities } \\
\text { (Std. error) }\end{array}$ \\
\hline Works council & $\begin{array}{l}0.568^{* * *} \\
(0.145)\end{array}$ & $\begin{array}{l}-0.022 \\
(0.057)\end{array}$ \\
\hline $\begin{array}{l}\text { Works council } \\
\text { Type A }\end{array}$ & $\begin{array}{l}0.673^{\star \star \star} \\
(0.145)\end{array}$ & $\begin{array}{c}0.062 \\
(0.061)\end{array}$ \\
\hline $\begin{array}{l}\text { Works council } \\
\text { Type B }\end{array}$ & $\begin{array}{c}0.271 \\
(0.185)\end{array}$ & $\begin{array}{l}-0.242^{* * *} \\
(0.086)\end{array}$ \\
\hline $\begin{array}{l}\text { p-value of F-test } \\
\mathrm{SE}_{\text {WoСо Туре A }}=\mathrm{SE}_{\text {WoСо Туре B }}\end{array}$ & 0.013 & $<0.001$ \\
\hline No. of obs. & \multicolumn{2}{|c|}{3662} \\
\hline
\end{tabular}

Notes: * statistically significant at 0.10 level; ${ }^{* *}$ at 0.05 level; ${ }^{* *}$ at 0.01 level. Standard errors are calculated by the delta method.

Regarding the estimates that control for different kinds of works councils, we still find that the likelihood of overemployment in codetermined establishments is higher than the likelihood of overemployment in non-codetermined establishments if the works council is characterized as a type A works council. We also find no significant effect of type B works councils on overemployment. Additionally, the null hypothesis of equality of these effects can still be rejected at 5\%-level. In the case of overpayment, our results are also similar to the previous results. The influence of type $A$ works councils is still insignificant and the marginal effect is very close to zero. Type $B$ 
works councils, however, still have a negative and highly significant coefficient. Both marginal effects are again significantly different from each other ( $p$-value: $<0.001$ ).

Summarizing our results, we find strong differences between the two types of works councils. Without controlling for heterogeneity, we find that establishments with works councils more frequently report problems with overemployment, but do not suffer from overpayment more frequently than establishments without this form of worker representation. Our findings are not easy to interpret on the basis of the property rights and the participation theory. The absence of complaints of too high wages supports the view of positive productivity effects of such an institution. The higher likelihood that managers will complain of overemployment is evidence in favor of the property rights theory ${ }^{12}$. Perhaps works councils have "two faces".

\section{INFERENCE USING OBJECTIVE MEASURES}

Given that our estimations are based on subjective measures of the economic situation and that the results concerning overpayment are somewhat surprising, we compare the results with objective measures. In doing so, we mainly repeat the approach of Pfeifer (2011) to estimate the impact of different types of works councils on wages ${ }^{13}$. Table $A 2$ in the appendix contains the results of a regression on In(wage) with both types of works councils as independent variables ${ }^{14}$.

Unfortunately, some establishments do not report their labor costs. Therefore the number of observations drops to 5281 in the large sample $(N>4)$ and to 3261 in the small sample $(N>20)$. The lower number of observations might affect the comparability of the estimates on wages and the estimates on our subjective variables if some establishments with a specific set of personnel problems do not state their labor costs. In order to test for such a possible selectivity bias, we also repeat the estimations on the subjective variables using the reduced number of

\footnotetext{
${ }^{12}$ This conclusion is not true with respect to type B works councils.

${ }^{13}$ Due to poor data, we only estimate wage equations and do not estimate production functions because the IAB Establishment Panel does not contain information about capital, and only contains an inaccurate definition of intermediate inputs.

${ }^{14}$ Note that, in contrast to our previous models, we forego the use of dummies for expected sales growth as independent variables in this model because such expectations should have no causal effect on recent average wage costs in an establishment.
} 
observations. These results are presented in Tables A4 to A6 of the appendix. The results of these regressions are almost identical to our previous results. Hence, on this basis, the hypothesis for a selection-induced bias finds no support.

Regarding the regressions on wages, we find a wage markup in codetermined establishments for both types of works council. However the markup is not of the same magnitude. Compared with establishments without a works council, wages in establishments with type A works councils are approx. 16 percent higher. Establishments with type B works councils, however, have a wage markup of approx. 13 percent. Both markups are also significantly different from each other at 5\%-level in both samples. Note that the management of establishments with type B works councils less frequently state that they suffer from overpayment. Hence, based on the results of the subjective and objective wage variables together, the wage markup in these establishments must be overcompensated by higher productivity. In establishments with type A works councils, wage markup and productivity seem to offset each other.

\section{CONCLUSION}

In this study, we examine whether, from the manager's point of view, codetermined establishments more frequently report having a high financial burden on wage costs and overemployment. Furthermore, we also consider heterogeneity in the behavior of works councils and investigate whether different types of works councils have different effects on the reported problems regarding payment and employment.

Our results show that in comparison with establishments without works councils codetermined establishments more frequently suffer from overemployment but do not suffer more frequently from overpayment. Apparently, higher wages in codetermined establishments that have been identified in previous studies seem not to be perceived as a problem by the management. Probably, higher productivity countervails.

According to our results the main effect of works councils is on employment and this impact is in accordance with the Works Constitution Act, which explicitly grants codetermination rights in this area. Works councils are (in theory) expected to abstain from wage bargaining. If they have an impact on remuneration this seems to 
be compensated by higher productivity. In our view these results also show that rent sharing is more than higher wages. Employment or employment protection is a highly valued good, which apparently is a determinant of the works councils' utility function.

As expected, in most cases works council do not lead to pareto improvements, as redistribution takes place. However this is not true for works councils of type $B$.

Finally, our results raise questions regarding future research. More research, especially on overemployment in codetermined establishments, is necessary. Is the higher likelihood of overemployment in codetermined establishments a temporary phenomenon, i.e. do works councils only delay dismissals, or does overemployment exist permanently? If the latter were true, do works councils lead to the implementation of efficient contracts because, for example, they are able to enforce their stability?

\section{REFERENCES}

Addison, J.T. / Schnabel, C. / Wagner, J. (2001): Works Councils in Germany: Their Effects on Firm Performance, Oxford Economic Papers 53, 659-694.

Addison, J.T. / Schnabel, C. / Wagner, J. (2004): The Course of Research into the Economic Consequences of German Works Councils, British Journal of Industrial Relations 42, 255-281.

Addison, J.T / Teixeira, P. / Zwick, T. (2010): Works Councils and the Anatomy of Wages, Industrial and Labor Relations Review 63, 250-274.

Beckmann M. / Föhr, S. / Kräkel, M. (2010): Rent Seeking, Employment Security, and Works Councils: Theory and Evidence for Germany, Schmalenbach Business Review 62: 2-40.

Booth, A.L. (1995): The Economics of the Trade Union, Cambridge, New York, Melbourne: Cambridge University Press.

Dilger, A. (2002): Ökonomik betrieblicher Mitbestimmung, Munich and Mering: Rainer Hampp Verlag.

Dilger, A. (2006): Kooperation zwischen Betriebsrat und Management: Die Sicht beider Seiten und deren Folgen, Jahrbücher für Nationalökonomie und Statistik 226: 562-587. 
FitzRoy, F. / Kraft, K. (1985): Unionization, wages, and efficiency: theories and evidence from the US and West Germany, Kyklos 38, 537-554.

FitzRoy, F. / Kraft, K. (1987): Efficiency and internal organization: Works councils in West German firms, Economica 54, 493-504.

FitzRoy, F. / Kraft, K. (1990): Innovation, rent-sharing and the organization of labor in the Federal Republic of Germany, Small Business Economics 2, 95-103.

Freeman, R.B. / Lazear, E.P. (1995): An Economic Analysis of Works Councils, in: Rogeers, J. I Streek, W. (eds.), Consultation, Representation, and Cooperation in Industrial Relations, Chicago and London: The University of Chicago Press.

Frege, C.M. (2002): A Critical Assessment of the Theoretical and Empirical Research on German Works Councils, British Journal of Industrial Relations 40, 221-248.

Gerlach, K. / Meyer, W. (2010): Wage Effects of Works Councils and Collective Agreements in Germany: The Anatomy of Wages and Productivity, in: C. Brown, B. Eichengreen and M. Reich (eds.), Labor in the Era of Globalization, Cambridge, New York, Melbourne, Madrid, Cape Town, Sao Paulo, Delhi, Dubai and Tokyo: Cambridge University Press , 295-316.

Gold, M. (1999): Innerbetriebliche Einflüsse auf die Beschäftigungsanpassung, in: Bellmann, L. I Kohaut, S. I Lahner, M. (eds.), Zur Entwicklung von Lohn und Beschäftigung auf der Basis von Betriebs- und Unternehmensdaten, Nürnberg: BeitrAB, 99-122.

Greene, W.H. (2008): Econometric Analysis, Upper Saddle River: Pearson Prentice Hall.

Hübler, O. I Jirjahn, U. (2003): Works Councils and Collective Bargaining in Germany: The Impact on Productivity and Wages, Scottish Journal of Political Economy 50, 1-21.

Jirjahn, U. (2005): Ökonomische Wirkungen des novellierten Betriebsverfassungsgesetzes - Was können wir vor dem Hintergrund zunehmender Globalisierung und veränderter arbeitsorganisatorischer Bedingungen erwarten?, Zeitschrift für Arbeitsmarktforschung 38, 241-267.

Jirjahn, U. (2011): Ökonomische Wirkung der Mitbestimmung in Deutschland: Ein Update, Schmollers Jahrbuch 131, 3-57.

Kölling, A. (2000): The IAB Establishment Panel, Schmollers Jahrbuch 120, 291-300.

Kotthoff, H. (1981): Betriebsräte und betriebliche Herrschaft: Eine Typologie von Partizipationsmustern im Industriebetrieb, Frankfurt and New York: Campus Verlag

Kotthoff, H. (1994): Betriebsräte und Bürgerstatus: Wandel und Kontinuität betrieblicher Mitbestimmung, Munich and Mering: Rainer Hampp Verlag. 
Kraft, K. (1986): Exit and Voice in the Labor Market: An Empirical Study of Quits, Journal of Institutional and Theoretical Economics 142, 697-715

Kraft, K. / Lang, J. (2008): The Causes and Consequences of Adopting a Works Council, Jahrbücher für Nationalökonomie und Statistik 228, 512-532.

Nienhüser, W. (2005): Der Einfluss des Betriebsrats-Typs auf die Nutzung und Bewertung von Betriebsvereinbarungen: Ergebnisse einer empirischen Untersuchung, Industrielle Beziehungen 12, 5-27.

Pfeifer, C. (2011): The Economic Consequences of Works Council Relations, Schmollers Jahrbuch 131, 59-71.

Pulte, P. (2009): Betriebsgröße und Arbeitsrecht. Birmingham: Verlag Personal, Recht, Management. 


\section{Appendix}

Table A1

Effects of works councils on overemployment and overpayment $(20<N)$

\begin{tabular}{|c|c|c|c|c|}
\hline \multicolumn{5}{|c|}{ Bivariate Probit } \\
\hline Variables & $\begin{array}{c}\text { Over- } \\
\text { employment } \\
\end{array}$ & $\begin{array}{c}\text { Over- } \\
\text { payment }\end{array}$ & \multirow[t]{2}{*}{$\begin{array}{l}\text { Over- } \\
\text { employment } \\
\\
\text { Coe } \\
\text { (Std.e }\end{array}$} & $\begin{array}{l}\text { Over- } \\
\text { payment }\end{array}$ \\
\hline Works council & $\begin{array}{l}0.313^{\star \star \star} \\
(0.079)\end{array}$ & $\begin{array}{l}-0.022 \\
(0.059)\end{array}$ & & \\
\hline Works council (Type A) & & & $\begin{array}{l}0.377^{\star \star *} \\
(0.082)\end{array}$ & $\begin{array}{c}0.063 \\
(0.063)\end{array}$ \\
\hline Works council (Type B) & & & $\begin{array}{c}0.154 \\
(0.108)\end{array}$ & $\begin{array}{l}-0.232^{\star \star \star} \\
(0.078)\end{array}$ \\
\hline Increasing sales & $\begin{array}{l}-0.233^{\star \star \star} \\
(0.069)\end{array}$ & $\begin{array}{l}-0.012 \\
(0.048)\end{array}$ & $\begin{array}{l}-0.230^{\star \star \star} \\
(0.069)\end{array}$ & $\begin{array}{l}-0.009 \\
(0.048)\end{array}$ \\
\hline Decreasing sales & $\begin{array}{l}0.679^{* * *} \\
(0.076)\end{array}$ & $\begin{array}{l}0.166^{\star *} \\
(0.067)\end{array}$ & $\begin{array}{l}0.680^{\star * \star} \\
(0.076)\end{array}$ & $\begin{array}{l}0.165^{\star \star} \\
(0.067)\end{array}$ \\
\hline Saturday & $\begin{array}{c}0.064 \\
(0.070)\end{array}$ & $\begin{array}{l}0.147^{\star * \star} \\
(0.052)\end{array}$ & $\begin{array}{c}0.061 \\
(0.070)\end{array}$ & $\begin{array}{l}0.147^{\star \star \star} \\
(0.052)\end{array}$ \\
\hline Temporary work & $\begin{array}{l}-2.193^{\star \star \star} \\
(0.713)\end{array}$ & $\begin{array}{l}-0.022 \\
(0.337)\end{array}$ & $\begin{array}{l}-2.240^{\star \star \star} \\
(0.729)\end{array}$ & $\begin{array}{l}-0.062 \\
(0.339)\end{array}$ \\
\hline Technology & $\begin{array}{l}-0.158^{\star \star} \\
(0.064)\end{array}$ & $\begin{array}{l}-0.119^{\star \star} \\
(0.049)\end{array}$ & $\begin{array}{l}-0.154^{\star *} \\
(0.064)\end{array}$ & $\begin{array}{l}-0.114^{\star \star} \\
(0.049)\end{array}$ \\
\hline $\begin{array}{l}\text { Collect. agreement } \\
\text { (firm level) }\end{array}$ & $\begin{array}{l}-0.015 \\
(0.103)\end{array}$ & $\begin{array}{l}0.013 \\
(0.078)\end{array}$ & $\begin{array}{l}-0.020 \\
(0.103)\end{array}$ & $\begin{array}{c}0.002 \\
(0.079)\end{array}$ \\
\hline $\begin{array}{l}\text { Collect. agreement } \\
\text { (industry level) }\end{array}$ & $\begin{array}{l}-0.032 \\
(0.072)\end{array}$ & $\begin{array}{l}0.106^{\star *} \\
(0.054)\end{array}$ & $\begin{array}{l}-0.040 \\
(0.073)\end{array}$ & $\begin{array}{r}0.096^{*} \\
(0.054)\end{array}$ \\
\hline Outsource & $\begin{array}{l}0.199^{*} \\
(0.115)\end{array}$ & $\begin{array}{l}0.145 \\
(0.100)\end{array}$ & $\begin{aligned} 0.198^{*} \\
(0.115)\end{aligned}$ & $\begin{array}{c}0.138 \\
(0.100)\end{array}$ \\
\hline Insource & $\begin{array}{r}0.232^{*} \\
(0.130)\end{array}$ & $\begin{array}{l}0.182^{*} \\
(0.104)\end{array}$ & $\begin{array}{l}0.215^{\star} \\
(0.130)\end{array}$ & $\begin{array}{c}0.161 \\
(0.104)\end{array}$ \\
\hline Single establishment & $\begin{array}{l}-0.002 \\
(0.064)\end{array}$ & $\begin{array}{c}0.014 \\
(0.050)\end{array}$ & $\begin{array}{l}0.008 \\
(0.064)\end{array}$ & $\begin{array}{c}0.022 \\
(0.050)\end{array}$ \\
\hline $\begin{array}{l}\text { Share of low-educated } \\
\text { workers }\end{array}$ & $\begin{array}{c}0.083 \\
(0.134)\end{array}$ & $\begin{array}{l}0.268^{\star \star \star} \\
(0.099)\end{array}$ & $\begin{array}{l}0.087 \\
(0.133)\end{array}$ & $\begin{array}{l}0.271^{\star \star \star} \\
(0.100)\end{array}$ \\
\hline $\begin{array}{l}\text { Share of highly educated } \\
\text { workers }\end{array}$ & $\begin{array}{l}-0.083 \\
(0.233)\end{array}$ & $\begin{array}{l}-0.470^{\star \star \star} \\
(0.177)\end{array}$ & $\begin{array}{l}-0.089 \\
(0.234)\end{array}$ & $\begin{array}{l}-0.484^{\star \star \star} \\
(0.177)\end{array}$ \\
\hline Share of part-time contracts & $\begin{array}{l}-0.010 \\
(0.184)\end{array}$ & $\begin{array}{l}-0.043 \\
(0.142)\end{array}$ & $\begin{array}{l}-0.021 \\
(0.184)\end{array}$ & $\begin{array}{l}-0.057 \\
(0.143)\end{array}$ \\
\hline $\begin{array}{l}\text { Share of fixed term } \\
\text { contracts }\end{array}$ & $\begin{array}{l}-0.065 \\
(0.301)\end{array}$ & $\begin{array}{c}0.112 \\
(0.203)\end{array}$ & $\begin{array}{l}-0.012 \\
(0.301)\end{array}$ & $\begin{array}{c}0.153 \\
(0.204)\end{array}$ \\
\hline Active owner & $\begin{array}{l}-0.065 \\
(0.070) \\
\end{array}$ & $\begin{array}{l}0.332^{\star \star \star} \\
(0.052)\end{array}$ & $\begin{array}{l}-0.056 \\
(0.070) \\
\end{array}$ & $\begin{array}{l}0.344^{\star \star \star} \\
(0.052) \\
\end{array}$ \\
\hline p-value of Wald test $[\rho=0]$ & & & & \\
\hline $\begin{array}{l}\text { McFadden- } R^{2} \\
\text { No. of obs. }\end{array}$ & & & & \\
\hline
\end{tabular}

Notes: See Table 2. 


\section{Table A2}

Effects of heterogeneous works councils on In(labor costs)

\begin{tabular}{|c|c|c|}
\hline \multicolumn{3}{|c|}{ OLS regression } \\
\hline $\begin{array}{l}\text { Sample } \\
\text { Variables }\end{array}$ & $\begin{array}{c}4<\mathrm{N} \\
\text { Coeff. } \\
\text { (Std.error) }\end{array}$ & $\begin{array}{c}20<\mathrm{N} \\
\text { Coeff. } \\
\text { (Std.error) }\end{array}$ \\
\hline Works council (Type A) & $\begin{array}{l}0.171^{\star \star \star} \\
(0.015)\end{array}$ & $\begin{array}{l}0.158^{\star \star \star} \\
(0.015)\end{array}$ \\
\hline Works council (Type B) & $\begin{array}{l}0.133^{\star * *} \\
(0.018)\end{array}$ & $\begin{array}{l}0.124^{\star \star \star} \\
(0.018)\end{array}$ \\
\hline Saturday & $\begin{array}{c}0.005 \\
(0.011)\end{array}$ & $\begin{array}{l}-0.006 \\
(0.013)\end{array}$ \\
\hline Temporary work & $\begin{array}{c}0.165^{\star} \\
(0.055)\end{array}$ & $\begin{array}{c}0.142 \\
(0.088)\end{array}$ \\
\hline Technology & $\begin{array}{l}0.020^{\star \star \star} \\
(0.011)\end{array}$ & $\begin{array}{c}0.012 \\
(0.011)\end{array}$ \\
\hline Collect. agreement (firm level) & $\begin{array}{l}0.042^{\star \star} \\
(0.017)\end{array}$ & $\begin{array}{l}0.034^{\star \star *} \\
(0.018)\end{array}$ \\
\hline Collect. agreement (industry level) & $\begin{array}{l}-0.008 \\
(0.011)\end{array}$ & $\begin{array}{l}-0.008 \\
(0.013)\end{array}$ \\
\hline Outsource & $\begin{array}{c}0.013 \\
(0.025)\end{array}$ & $\begin{array}{c}0.029 \\
(0.025)\end{array}$ \\
\hline Insource & $\begin{array}{c}0.036 \\
(0.024)\end{array}$ & $\begin{array}{l}0.051^{\star *} \\
(0.025)\end{array}$ \\
\hline Single establishment & $\begin{array}{l}-0.026^{* *} \\
(0.011)\end{array}$ & $\begin{array}{l}-0.018 \\
(0.012)\end{array}$ \\
\hline Share of low-educated workers & $\begin{array}{l}-0.265^{\star \star \star} \\
(0.024)\end{array}$ & $\begin{array}{l}-0.254^{\star \star \star} \\
(0.027)\end{array}$ \\
\hline Share of highly educated workers & $\begin{array}{l}0.700^{\star \star \star \star} \\
(0.034)\end{array}$ & $\begin{array}{l}0.728^{\star \star \star} \\
(0.041)\end{array}$ \\
\hline Share of part-time contracts & $\begin{array}{l}-0.830^{* * \star} \\
(0.038)\end{array}$ & $\begin{array}{l}-0.781^{* * *} \\
(0.050)\end{array}$ \\
\hline Share of fixed term contracts & $\begin{array}{l}-0.078^{*} \\
(0.046)\end{array}$ & $\begin{array}{l}-0.238^{\star \star \star} \\
(0.058)\end{array}$ \\
\hline Active Owner & $\begin{array}{l}-0.043^{\star * *} \\
(0.011)\end{array}$ & $\begin{array}{l}-0.031^{* * *} \\
(0.012)\end{array}$ \\
\hline $\begin{array}{l}\text { No. of obs. } \\
\mathrm{R}^{2}\end{array}$ & $\begin{array}{l}5281 \\
0.552\end{array}$ & $\begin{array}{l}3261 \\
0.600\end{array}$ \\
\hline$p$-value of F-test $\left[\beta_{\text {WoСo Type A }}=\beta_{\text {WoСо Туре B }}\right]$ & 0.018 & 0.033 \\
\hline
\end{tabular}

Notes: See Table 2. 
Table A3

Regression results of the main independent variables without establishments that do not state labor costs (full sample)

\begin{tabular}{|c|c|c|c|c|}
\hline \multicolumn{5}{|c|}{ Bivariate Probit } \\
\hline Variables & $\begin{array}{r}\text { Over- } \\
\text { employment } \\
\mathrm{C} \\
(\mathrm{Stc}\end{array}$ & $\begin{array}{l}\text { Over- } \\
\text { payment } \\
\end{array}$ & \multicolumn{2}{|c|}{$\begin{array}{cc}\text { Over- } & \text { Over- } \\
\text { employment } & \text { payment } \\
\text { Coeff. } & \\
\text { (Std.error) }\end{array}$} \\
\hline Works council & \multirow[t]{3}{*}{$\begin{array}{l}0.296^{\star \star \star} \\
(0.077)\end{array}$} & \multirow[t]{3}{*}{$\begin{array}{l}-0.058 \\
(0.057)\end{array}$} & & \\
\hline Works council (Type A) & & & $\begin{array}{l}0.373^{* * *} \\
(0.082)\end{array}$ & $\begin{array}{c}0.011 \\
(0.061)\end{array}$ \\
\hline Works council (Type B) & & & $\begin{array}{c}0.100 \\
(0.109)\end{array}$ & $\begin{array}{l}-0.226^{\star \star *} \\
(0.077)\end{array}$ \\
\hline p-value of Wald test $[\rho=0]$ & & \multicolumn{2}{|c|}{$<0.001$} \\
\hline McFadden- $\mathrm{R}^{2}$ & \multicolumn{2}{|c|}{0.073} & \multirow{2}{*}{\multicolumn{2}{|c|}{0.074}} \\
\hline No. of obs. & & & & \\
\hline
\end{tabular}

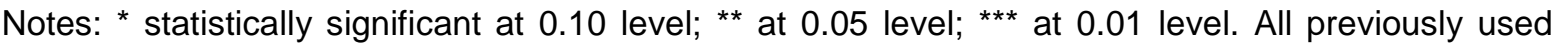
covariates are included but not reported. Robust standard errors in parenthesis.

Table A4

Effects of works councils on overemployment and on overpayment variables without establishments that do not state labor costs (full sample)

\begin{tabular}{|c|c|c|}
\hline Variables Dep. Var. & $\begin{array}{l}\text { Overemployment } \\
\text { Marginal effects } \\
\text { (Std. error) }\end{array}$ & $\begin{array}{l}\text { Overpayment } \\
\text { Marginal effects } \\
\text { (Std. error) }\end{array}$ \\
\hline Works council & $\begin{array}{l}0.047^{\star \star \star} \\
(0.013)\end{array}$ & $\begin{array}{l}-0.021 \\
(0.020)\end{array}$ \\
\hline Works council (Type A) & $\begin{array}{l}0.062^{\star \star \star} \\
(0.015)\end{array}$ & $\begin{array}{c}0.004 \\
(0.022)\end{array}$ \\
\hline Works council (Type B) & $\begin{array}{c}0.016 \\
(0.016)\end{array}$ & $\begin{array}{l}-0.078^{\star \star \star} \\
(0.026)\end{array}$ \\
\hline \multirow{3}{*}{$\begin{array}{l}\mathrm{p} \text {-value of F-test } \\
M E_{\text {WoCo Type A }}=\mathrm{ME}_{\text {WoСo Type B }}\end{array}$} & & \\
\hline & 0.006 & 0.000 \\
\hline & $\begin{array}{l}\text { Semi-elasticities } \\
\text { (Std. error) }\end{array}$ & $\begin{array}{c}\text { Semi-elasticities } \\
\text { (Std. error) }\end{array}$ \\
\hline Works council & $\begin{array}{l}0.552^{\star * \star} \\
(0.143)\end{array}$ & $\begin{array}{l}-0.060 \\
(0.060)\end{array}$ \\
\hline $\begin{array}{l}\text { Works council } \\
\text { Type A }\end{array}$ & $\begin{array}{l}0.685^{\star \star \star} \\
(0.145)\end{array}$ & $\begin{array}{c}0.011 \\
(0.063)\end{array}$ \\
\hline $\begin{array}{l}\text { Works council } \\
\text { Type B }\end{array}$ & $\begin{array}{c}0.188 \\
(0.200)\end{array}$ & $\begin{array}{l}-0.246^{\star \star \star} \\
(0.091)\end{array}$ \\
\hline $\begin{array}{l}p \text {-value of F-test } \\
\mathrm{SE}_{\text {WoСo Type A }}=\mathrm{SE}_{\text {WoСо Туре В }}\end{array}$ & 0.005 & 0.002 \\
\hline
\end{tabular}

Notes: * statistically significant at 0.10 level; ${ }^{* \star}$ at 0.05 level; ${ }^{\star \star *}$ at 0.01 level. Standard errors are calculated by the delta method. 
Table A5

Regression results of the main independent variables without establishments that do not state labor costs $(\mathrm{N}>20)$

\begin{tabular}{|c|c|c|c|c|}
\hline \multicolumn{5}{|c|}{ Bivariate Probit } \\
\hline Variables & \multicolumn{2}{|c|}{$\begin{array}{c}\text { Coeff. } \\
\text { (Std.error) }\end{array}$} & \multicolumn{2}{|c|}{$\begin{array}{cc}\text { Over- } & \text { Over- } \\
\text { employment } & \text { payment } \\
\text { Coeff. } & \\
\text { (Std.error) } & \end{array}$} \\
\hline Works council & $\begin{array}{l}0.293^{\star \star \star} \\
(0.082)\end{array}$ & $\begin{array}{l}-0.061 \\
(0.062)\end{array}$ & & \\
\hline Works council (Type A) & & & $\begin{array}{l}0.360^{* \star *} \\
(0.086)\end{array}$ & $\begin{array}{c}0.009 \\
(0.066)\end{array}$ \\
\hline Works council (Type B) & & & $\begin{array}{c}0.127 \\
(0.113)\end{array}$ & $\begin{array}{l}-0.231^{\star \star \star} \\
(0.082)\end{array}$ \\
\hline p-value of Wald test $[\rho=0]$ & \multirow{2}{*}{\multicolumn{2}{|c|}{$\begin{array}{c}<0.001 \\
0.071\end{array}$}} & \multicolumn{2}{|c|}{$<0.001$} \\
\hline McFadden- $\mathrm{R}^{2}$ & & & \multicolumn{2}{|c|}{0.073} \\
\hline No. of obs. & \multicolumn{4}{|c|}{3261} \\
\hline
\end{tabular}

Notes: See Table A3.

Table A6

Effects of works councils on overemployment and on overpayment without establishments that do not state labor costs $(\mathrm{N}>20)$

\begin{tabular}{|c|c|c|}
\hline Variables Dep. Var. & $\begin{array}{l}\text { Overemployment } \\
\text { Marginal effects } \\
\text { (Std. error) }\end{array}$ & $\begin{array}{l}\text { Overpayment } \\
\text { Marginal effects } \\
\text { (Std. error) }\end{array}$ \\
\hline Works council & $\begin{array}{l}0.051^{\star \star \star} \\
(0.014)\end{array}$ & $\begin{array}{l}-0.023 \\
(0.023)\end{array}$ \\
\hline Works council (Type A) & $\begin{array}{l}0.065^{\star \star \star} \\
(0.016)\end{array}$ & $\begin{array}{c}0.003 \\
(0.025)\end{array}$ \\
\hline Works council (Type B) & $\begin{array}{c}0.023 \\
(0.022)\end{array}$ & $\begin{array}{l}-0.083^{\star \star \star} \\
(0.029)\end{array}$ \\
\hline \multirow{2}{*}{$\begin{array}{l}\text { p-value of of F-test } \\
\mathrm{ME}_{\text {WoСо Туре A }}=\mathrm{ME}_{\text {WoСо Туре B }}\end{array}$} & 0.029 & 0.002 \\
\hline & $\begin{array}{l}\text { Semi-elasticities } \\
\text { (Std. error) }\end{array}$ & $\begin{array}{l}\text { Semi-elasticities } \\
\text { (Std. error) }\end{array}$ \\
\hline Works council & $\begin{array}{l}0.530^{\star \star \star} \\
(0.151)\end{array}$ & $\begin{array}{l}-0.059 \\
(0.060)\end{array}$ \\
\hline $\begin{array}{l}\text { Works council } \\
\text { Type A }\end{array}$ & $\begin{array}{l}0.640^{\star \star *} \\
(0.153)\end{array}$ & $\begin{array}{c}0.009 \\
(0.064)\end{array}$ \\
\hline $\begin{array}{l}\text { Works council } \\
\text { Type B }\end{array}$ & $\begin{array}{c}0.224 \\
(0.195)\end{array}$ & $\begin{array}{l}-0.237^{\star \star \star} \\
(0.089)\end{array}$ \\
\hline $\begin{array}{l}p \text {-value of F-test } \\
S E_{\text {WoСo Type A }}=S E_{\text {WoСo Туре B }}\end{array}$ & 0.015 & 0.003 \\
\hline
\end{tabular}

Notes: See Table A4. 